\title{
Why Do Companies Use Performance-Related Pay for Their Executive Directors?*
}

\author{
Ruth Bender**
}

This paper sets out the results of interview-based research to determine why companies use performance-related pay. The findings indicate that many companies adopt this structure despite a belief that the money does not motivate executives. Reasons related in part to best practice in human resource management: pay structures were designed to attract and retain executives with the potential of large earnings; to focus their efforts in the direction agreed by the board; and to demonstrate fairness. Importantly, the variable pay was seen as a symbol of the director's success, both internally and to his or her peers in other companies. Finally, and significantly, an institutional theory explanation was given: companies used performancerelated pay because their peers did, and because that legitimised them in the eyes of the establishment.

Keywords: Remuneration, corporate governance, agency theory, motivation, institutional theory, legitimacy

\section{Introduction}

$\mathbf{T}$ he remuneration of executive directors of listed companies is an issue that has attracted wide public concern, as well as the interest of academic researchers. Regulators have set down layers of rules and guidelines (e.g. Department of Trade and Industry (DTI), 2002). Institutional shareholders have expressed their concern in various recommendations (e.g. Association of British Insurers (ABI), 2002). And the press and other media have kept the issue in the public eye with articles on the "fat cat" directors and the vast amounts they are awarded (e.g. The Economist, 2003).

In both the public arena and scholarly research, one issue that is considered over and again is the structure of directors' pay, and in particular the relative proportions of the fixed and variable elements. It is generally considered to be best practice for a large amount of the remuneration to be dependent on performance. Indeed, the Combined Code on Corporate Governance states that "a significant proportion of executive directors' remuneration should be structured so as to link rewards to corporate and individual performance" (2003, para B.1). This is an increased requirement from the previous version of the Code, which demanded only that "a proportion" of pay be performancerelated - evidence that variable pay is seen as becoming more important.

This United Kingdom regulation reflects a wider trend, with governance regulations in other jurisdictions also requiring a link between executive pay and performance. Examples can be seen in the United States' tax code requirement $162(\mathrm{~m})$ that top executive pay in excess of US\$1m can only be taxdeductible if it is performance-related (Cornell Law School, Legal Information Institute, undated), and in the OECD governance principles (OECD, 2004, p. 36).
*This paper was presented at the 6th International Conference on Corporate Governance and Board Leadership, 6-8 October 2003 at the Centre for Board Effectiveness, Henley Management College.

** Address for correspondence: Cranfield School of Management, Cranfield, Bedfordshire MK43 0AL, UK. Tel: +44 1234 751122; Fax: +44 1234751806 ; E-mail: r.bender@cranfield. ac.uk 
Given the focus on performance-contingent remuneration by both practitioners and academics, this paper makes a timely contribution to the debate. In a UK context, it sets out the results of one of the few pieces of interviewbased research in the field (see also Conyon $e t$ al., 2000). The aim of the paper is to present research which shows how participants in the remuneration-setting process see the use of performance-related pay. It adds to the body of knowledge by going beyond the statistical analyses which show whether pay is linked to performance - it starts to answer the question why. It is hoped that both the scholarly debate and current practice will be informed by these results.

\section{Prior research}

In the many decades of scholarly research into directors' remuneration, the main theoretical perspective taken has been an economic one, using an agency theory approach. Agency theory (Jensen and Meckling, 1976) examines the relationship between principals (in this case shareholders) and agents (in this case the executive directors). It sees there to be an inherent conflict of interest in the relationship: directors, portrayed as risk-averse and workshy, have an incentive to run the company for their own benefit, which conflicts with the owners' desire for shareholder value. The complexity of the directors' role means that the shareholders cannot effectively monitor their every action and decision. Accordingly, agency theory sees the structure of remuneration contracts as one way of motivating the directors to manage the company in line with the shareholders' wishes. (For a fuller explanation of agency theory see Eisenhardt (1989) or Hart (1995).)

Prendergast (1999) suggests that there are three main assumptions underlying agency theory. The first of these is that there is in fact a conflict of interest between the directors and the shareholders. Not all of the participants in the debate believe this (Davis et al., 1997). However, it is a common assumption, and one that also seems to underlie the broader, nonacademic debate as seen in the Combined Code (2003), and that assumption is not challenged in this paper. The second two assumptions suggested by Prendergast are that the directors can be motivated to do as the shareholders wish by using a form of performancerelated pay; and that their contracts are written in such a way as to facilitate this. These latter two assumptions are considered in this research. If agency theory tenets underlie the use of performance-related pay, we would expect the research findings to demonstrate that those determining the remuneration structure do so to induce directors to work harder and take risks, in the expectation that the prospect of earning the reward will motivate such behaviour.

Given the agency theory assumption that directors can be motivated by monetary reward, it is appropriate to look too at the academic literature on motivation. In particular, two aspects are considered - whether money motivates and, if so, how money motivates.

The question "does money motivate?" is one which has been considered by many researchers. Deci (1972) discussed two kinds of motivation - extrinsic and intrinsic. Extrinsic motivation relates to what is done by others to motivate employees - for example, paying them a performance-related bonus. However, intrinsic motivation relates not to outside influences but to the individual employee, and derives from the individual's satisfaction in doing the job. An argument put forward (Ambrose and Kulik, 1999; Milkovich and Newman, 2002) is that intrinsic motivation is more powerful than extrinsic, and, indeed, that the use of an extrinsic driver will decrease the employee's intrinsic motivation, and thus reduce his or her job performance. Osterloh and Frey (2002) explain this as being because extrinsic rewards "crowd out" intrinsic motivation, to the possible detriment of performance. However, one of their arguments for this is that the external reward has the effect of reducing the autonomy of the employee, thus reducing his or her intrinsic motivation; given that this research focuses on executive directors, this perceived lack of autonomy seems unlikely to be relevant.

Assuming for the moment that extrinsic measures do provide motivation, it is also useful to see how they might work. Two theories are useful in considering this expectancy theory and equity theory. Expectancy theory (Vroom, 1964; Bonner and Sprinkle, 2002) states that employees will only be motivated by a reward if they see that reward as being something worthwhile; believe that they will receive the reward for achieving the appropriate performance; and can see how they could achieve that performance. If those conditions are in place, the individual has an incentive to achieve the relevant performance. Equity theory (Adams, 1963) relates to equity between individuals, or, perhaps more correctly, inequity between individuals. It suggest that employees look to a relevant comparator other (for example, someone on the same grade within the company, or someone doing a similar job in a different company) and compare the ratio of 
their inputs (how hard they work) and outputs (what they get paid) with that relevant other's. If the ratio indicates that their input/output ratio is too high (which would occur if they were relatively underpaid) or too low (overpaid) then they will act to redress the inequity. The relevance of this to the research is that an equity theory explanation would place the emphasis of performance-related pay on a comparison with others, both internally and externally, rather than just considering the absolute monetary incentive.

A further consideration on the subject of motivation arises from one of the classic texts on the subject. Maslow (1970) discusses motivation in terms of the hierarchy of needs, suggesting that we first need to satisfy our physiological needs then, in order, safety needs, love needs, esteem needs (self esteem and the esteem of others) and self actualisation. He points out that a satisfied need is not a motivator of behaviour. For senior executives it seems unlikely that the sums of money being paid are necessary to meet the lower level needs, and there must be a supposition that a main function of the reward is to meet the executive's needs for self esteem and recognition.

Before moving on to discuss the research itself, it is useful to consider one more theoretical perspective on performance-related pay. As discussed earlier, there has been much regulation in this area. In this context, institutional theory and legitimacy theory may be relevant. Proponents of institutional theory (DiMaggio and Powell, 1983; Scott, 1995) take the view that often companies structure themselves in order to be like other companies, rather than for reasons tailored to their individual circumstances. Explanations given for that include coercive isomorphism (the need to meet the requirements of regulators) and mimetic isomorphism (the desire to be like other companies which are perceived as good). Linked to both of these is the concept of legitimacy (Harrison, 1987; Suchman, 1995), which suggests that companies need to structure their activities in order to achieve legitimacy in the constituencies from which they draw resources. In defining legitimacy, Suchman stated that it is "a generalized perception or assumption that the actions of an entity are desirable, proper or appropriate within some socially constructed system of norms, beliefs and definitions" (1995, p. 574). In the context of this research, it is useful to consider this motive for using performancerelated pay. It is possible that these pay structures are adopted not so much to enhance performance, but merely so that the company meets "best practice" and does not attract adverse attention from, for example, its institutional shareholders.

\section{Research design}

The majority of UK listed companies structure the remuneration of their executive directors so that it includes a significant proportion of variable pay, in the form of annual bonuses, dependent on short-term performance measures, and schemes which reward the achievement of longer term performance measures and run for three or more years (New Bridge Street Consultants, 2002a, 2002b). The objective of this research, which is part of a larger project, is to address the question "Why do companies use performance-related pay?" Specifically, for a sample of FTSE 350 companies it examines the different reasons given for using both short-term and longer term performance-related pay, and considers whether and how these can be explained by existing theory.

Most of the research in this field takes a positivistic approach and analyses archival data (Merchant et al., 2003). However, this research addresses a "why" question, and one which has not been fully addressed by previous research. Accordingly, this is partly an exploratory and partly a descriptive study. Thus a case study design was seen as the most appropriate (Yin, 1993).

This study reflects interviews at 12 companies, with 35 individuals. Of the companies, nine were in the FTSE 100 and three were in the FTSE 250. Six companies were selected from the PricewaterhouseCoopers corporate register $^{1}$ (19 companies were so selected and cold-called; these six agreed to participate). Four companies agreed to participate in the research following a circular letter to a corporate network of about 30 companies, and two companies were approached after they expressed interest in the research during a presentation of some early results (Bender, 2003). Table 1 sets out descriptive statistics of the interviewees.

It can be seen that the number of interviewees varied between companies. The original research design was to conduct semistructured interviews with five individuals at each company: the responsible human resources (HR) professional, the chief executive officer (CEO), the chairman of the remuneration committee, another non-executive director (NED) and the consultant they used. Initial discussions prior to commencing the research had indicated that these five roles contributed most to the determination of directors' pay. However, some companies offered more individuals for interview, whilst in others the par- 
Table 1: Descriptive statistics of the interviewees

\begin{tabular}{|c|c|c|c|c|c|c|c|c|}
\hline Co. & $\begin{array}{l}\text { HR } \\
\text { professional }\end{array}$ & $\begin{array}{l}\text { Committee } \\
\text { chairman }\end{array}$ & NED & Consultant & CEO & $\begin{array}{l}\text { Company } \\
\text { secretary }\end{array}$ & $\begin{array}{l}\text { Company } \\
\text { chairman }\end{array}$ & Total \\
\hline 1 & 2 & 1 & 1 & 1 & 1 & & & 6 \\
\hline 2 & 1 & 1 & 1 & 1 & 1 & & & 5 \\
\hline 3 & 1 & & & & & & & 1 \\
\hline 4 & 1 & 1 & & & 1 & & & 3 \\
\hline 5 & 1 & & 1 & 1 & & 1 & 1 & 5 \\
\hline 6 & 2 & & & & & & & 2 \\
\hline 7 & 1 & 1 & 2 & 1 & 1 & 1 & & 7 \\
\hline 8 & 1 & & & 1 & & & & 2 \\
\hline 9 & 1 & & & & & & & 1 \\
\hline 10 & 1 & & & & & & & 1 \\
\hline 11 & & & & & & 1 & & 1 \\
\hline 12 & & 1 & & & & & & 1 \\
\hline Total & 12 & 5 & 5 & 5 & 4 & 3 & 1 & 35 \\
\hline
\end{tabular}

ticipation was limited, due either to the companies' willingness to commit to the research or to the availability of directors for interview.

These interviews were conducted between December 2001 and May 2003. In addition, the research findings were confirmed and extended in interviews with an institutional representative, two head-hunters and a focus group brought together for respondent validation (Miles and Huberman, 1994).

The interviews typically lasted about an hour. Other than the focus group, all interviews except three were taped and transcribed, and transcripts were sent to the interviewees for confirmation. (Of the three, one participant did not want to be taped, one was a "spontaneous" meeting and one recording failed.) In addition to the transcripts (which have been coded with the aid of NVivo), extensive notes were taken. To supplement the interviews, documentary sources were used. These included: the companies' financial statements for the current and preceding years (and subsequent years when available); analysts' reports on the companies; and press reports on directors' remuneration in the companies. Five of the companies made available some or all of the internal documentation surrounding the remuneration-setting process, for example, minutes of remuneration committee meetings and consultants' reports.

Of the interviewees, only five were women. Accordingly, in order to protect confidentiality, all participants and all executives are referred to as "him", regardless of gender.

Every company in the study used a significant element of variable pay, adopting both short-term and long-term schemes. Of those companies that disclosed a pay structure in their published remuneration reports, the level of fixed pay varied between 35 per cent and 50 per cent of the total pay for on-target performance. This reflects survey data presented by consultants, for example New Bridge Street Consultants (2002a, 2002b).

\section{Findings}

In this section the research findings as to why companies use performance-related pay (PRP) are discussed. In coding the interviews, two main sets of reasons emerged for its use - PRP is used for strategic HR purposes, and it is used to confer legitimacy. These are discussed below. The section concludes with a brief discussion of the problems encountered in using PRP.

\section{HR reasons for using performance-related pay}

Pay as a motivator

I'm not motivated by money. The bonuses are a large amount of money, but the [Skandia] board put the schemes in place to incentivise people.

(Alan Wilson, chief executive of Skandia UK, in Financial Times, 2003)

The above comment illustrates the confusion of ideas expressed by many of the participants - that PRP can "incentivise", but not "motivate" $^{\prime \prime}$. It is a basic assumption of agency theory that paying individuals to achieve results will 
motivate them to work harder and result in better outcomes for the organisation. However, when this point was put to the interviewees, their responses were mixed. Several took the view that pay did indeed motivate performance, whilst others argued that it did not. Although some of the HR professionals referred to research on the motivational impact of performance-related pay, many of the arguments made seemed to come from the interviewees' experience and belief. The points raised reflected issues such as whether pay ever motivated, or whether it motivated at the executive level under consideration in this research.

Some took the view that performancerelated pay was a motivating factor, and that it did incentivise people to perform, inasmuch as people needed an incentive to outperform.

Why should people take risks - because there is some reward.

NED

There's a risk [if pay were at a flat rate] that they may not be focused on extending the business as far as they could, in the knowledge that the fee was achievable irrespective of performance. There's a possibility that psychologically they could under-perform and not stretch themselves. There's a risk I think from the individual perspective that potential for improvement through salary would be lost. A lot of our people at the top of the organisation are quite driven by the prospect of personal wealth, and flat fees, and the level of them, seem to us to remove one of the carrots, incentives to get people to do more. For some people there's a tendency to slide back into average behaviour if they know that their pay outcomes are not rewarding extra effort and extra success.

HR director

... we unashamedly believe that people are motivated by pride and by money.

Committee chairman

Paying everybody the same base salary with no additional rewards, you will do what you've always done and get what you've always got.

$H R$ director

However, other interviewees did not believe that pay influenced effort at a senior level of the business.

I'm not sure that anyone believes in practice that it makes very much difference. Especially at the very senior level of the organisation. Senior managers are motivated by something other than pure salary.

Company secretary
I'm highly sceptical myself as to how much extra people really put in. It has an impact, it does have an impact. But I think... it depends on the market you're in, but I think it can be overplayed.

and

Q: If they were on flat salaries would they work the same?

A: I think it is very marginal, particularly for people right at the top of the organisation. Because they are just highly motivated people who wouldn't be there otherwise.

CEO

And, from a different CEO:

I wouldn't want to feel exploited. . . . But I don't come to work every day and think "if I work even harder do I get paid even more?". It just doesn't work like that.

CEO

And one participant summed up both sides of the argument:

And obviously there is always a moment in time where probably you put in that little extra effort because you might get additional reward. But I very seldom see people, say, work longer hours or work differently or become suddenly more intelligent because they are performance-related.

CEO

Outside of the simplicity of the argument that says "pay does motivate" or "it does not", some comments were made which indicated that the influence of performance-related pay was more subtle, and context-dependent. Some argued that it would influence some individuals more than others.

So we have an aggressive bonus, which is only ever paid on a profit-sharing scheme. So this of course attracts a certain sort of person.

NED

We have some people whom I have heard being described as "coin operated". They're here for the money, and that's it. You get those sort of people in marketing. Given a big bonus to go for and bam! But you get other people, for example - I'm generalising now - and this is below executive level, guys who work in [business area]. Yes, you've got to get the hygiene factors right, but they don't particularly want to earn socking great amounts of money. These are people who have very strong vocational interests, and as long as they are earning a reasonable amount, that's it.

CEO

A consultant suggested that interview responses would suggest that performance- 
related pay did inspire effort - but not for the individual himself.

If you ask most people on the impact of performance linked pay you get a very typical answer. I suspect you get it from all of us. "No, it doesn't influence me. I am a professional manager with a very, very high level of commitment, and I'm not going to be influenced by anything as lowly as material gain. However, in managing the part of the business that I manage I find that incentive pay to the people within that business really has an impact." (Laughs) And you can go down through an organisation and you get broadly similar comments.

Consultant

In this he was correct: none of the individuals interviewed stated outright that he personally worked harder because of the incentives he was offered.

It can be seen that the interviewees were divided as to whether money was indeed a motivator. Further, in this part of the discussion there is no evidence that schemes are devised based on the principles suggested by either equity theory or expectancy theory. However, the participants were clear that the lack of money was a demotivator. That being so, it was apparent that the pay represented something beyond its cash value, and the symbolic value of pay is now considered.

Pay as a symbol of worth

Teachers in schools do it with gold stars; in business you do it with money.

CEO

This comment illustrates the power of money as a symbol of success. One of the other interviewees, a remuneration consultant, suggested that once a director reaches the top of the company there is less formal appraisal and feedback, and so the amount of money earned is the main indicator he has of his value. ${ }^{2}$ This is a symbol to him, to the rest of the company, and also to his peers. It is a clear way by which he can benchmark himself against his peers a measure of success.

... the majority of directors that I know are egotistical and have a personal pride in success. They are peer-conscious. They want to be seen to be doing better than the others.

NED

The amount earned - which, of course, is publicly disclosed - thus becomes a matter of self esteem for the executives. This can be seen in following extracts, discussing this aspect of the use of PRP.
And the ego of the senior corporate man is a well-known fact of life, and it's a very good way of using that to get very focused achievement. And that's perhaps the most effective way in which you align an executive's performance with the chosen strategy of the company.

HR manager

And there's absolutely no doubt that some of this pressure, particularly at the top, the very large rewards, comes from a tendency of businessmen to compare themselves with other people. And I would describe it as a sort of macho desire to be seen publicly to be a success. And part of being a success is not only the job you hold, it's the effectiveness with which you have negotiated your reward.

Committee chairman

At senior level, it's not the $£ 50,000$ plus or minus that counts, it's the fact that it's a communication of performance.

Consultant

Thus the level of pay, and particularly the performance-related award, serve a symbolic purpose over and above their monetary worth. By the same token, should an executive receive an award substantially less than his peers, the damage to his self esteem may outweigh the monetary disadvantage.

... if you get it wrong, if there is a problem or crisis and you don't handle it properly, you will find, and you'll see it in the end, that you're earning far less in that year in incentive terms than your peer group. And that is a humiliation, not just a loss of money. It gives you a bad feeling. And it's meant to.

Committee chairman

Focus

A standard agency theory explanation for using PRP is that it makes the agent work harder, preventing "shirking". That explanation was not accepted by any of the interviewees.

Q: What I'm curious to understand, as everybody seems to take it for granted, is do people work harder for performance-related pay? Or better? What's the advantage of it?

A: I don't know that people work harder. I can't actually prove that they work better. I think what it does do, because performance has to be related to measurement, is it does enable you to provide very clear, measurable targets/objectives against which people get rewarded.

Committee chairman

As illustrated above, the most common explanation given by interviewees for why compa- 
nies use PRP was that it provides a focus to executives for their work efforts. This is in line with another aspect of agency theory: that contracts are designed to mitigate the multi tasking problem (Holstrom and Milgrom, 1991). Indjejikian (1999) pointed out that the executives have many different responsibilities, and could see them as complements to each other, or as substitutes. He suggested that the real agency conflict is about ensuring that executives focus on the responsibilities and actions that are seen by the board as most important.

In line with this, interviewees pointed out that the performance measures were a signal of what the organisation saw as important, and what they should be concentrating on in the short term. The word "focus" was used a lot in discussing these issues.

It certainly going to focus you on the things which are seen by the company to be important. Consultant

I think that they focus minds if they are well-designed.

NED

So I don't doubt the fact that they work hard. I actually think that if the board and the management get it right then it delivers a focus to what they should be doing; i.e. they don't have flights of fancy in terms of extra-core acquisitions and things. It actually applies a focus to the way in which they do their business. I think that that is what it gives, rather than working any harder.

NED

So it's a tool to assist the chief executive in getting very focused performance out of his reports.

HR manager

Other points raised along the same lines related to the need to provide a clear message to the executives and throughout the firm, using the variable pay (and particularly the annual bonus) to communicate a message throughout the organisation. It sends a clear message to the CEO about what the board thinks is important, and to the rest of the company about what the CEO believes is important. Indeed, it was suggested by one HR manager that there was little point in setting objectives in the organisation if the reward system did not recognise them - they would not be seen as serious. In this respect, the variable pay is a way of communicating strategy.

Linked to this, some companies had introduced different performance measures on annual awards specifically to encourage a change in culture and attitudes. In a couple of companies, the performance measures represented goals that the company needed to achieve to make a step-change in its performance. In this, the performance measures can be seen as symbols.

We all, I think, began to reflect the view that the incentives needed to change, to meet both our aspirations and the changing shape of the business.

HR professional

That epitomises what it's been about. So, if you like, the incentive plans - or at least the short term incentive plans - have been designed to support that particular objective.

HR professional

In the desire to create focus on key objectives, companies had used different types of performance measures, to accommodate differences in their cultures and structures and in their aims. Some implemented both financial and non-financial measures, others used just financial ones. Some rewarded individual targets, others tried to inculcate a group sense of shared responsibility by adopting solely group targets. The importance of aligning measures and targets to business objectives was generally agreed, although many participants believed that this was the greatest challenge of PRP, as it is difficult to select meaningful measures and appropriate targets for the most senior levels of employee.

\section{Fairness}

Many of the interviewees referred to the need for fairness as a reason for awarding performance-related pay. However, meanings of "fair" differed. One aspect of fairness was fairness between employees in the same company, so that higher-performing workers received higher rewards.

I think performance measures that fairly incentivise people - and being fair is the key - ... incentives that are fair and recognise the exceptional performer for going the extra mile is entirely appropriate in the business.

HR manager

We want rewards to encourage people to do better, to do as well as they can. And we wish in some way to distinguish between those who are performing and those who aren't.

Committee chairman

Another aspect of fairness was fairness between the director and his peers in other companies. The argument was put that directors should have the same opportunity to earn large sums as did their peers. One reason 
given was that this was necessary in order to attract good people to the company, and to retain their services.

What [CEO] wants and expects is to be paid fairly. He would regard being paid fairly in two ways. One, that the basic amount he gets is reasonably comparable with those that he regards as his peers outside. And the second thing he'd expect is that if he and the company perform better, he gets paid more. Now that is what he would regard as being treated fairly. So if he didn't get that he would regard himself as being treated unfairly. Whether that would have the effect of him working less hard, I don't think it is that simple. Because I think he'd probably still work as hard, but if somebody is less happy, less content with life, their performance would tend to go down. And he might also look for somewhere else, or have looked somewhere else. Because the other thing is you want to retain someone. And if they are unsettled. ... Most of pay, in my view, is hygiene. And that includes performance, it's not just the base. But it's very easy to lose it. You're most certainly not perfect, so it's how little imperfect you can be.

HR manager

What I think is probably more important than absolute reward is relative reward. And I think that people are conscious of what's going on out there, and that they don't want to feel undervalued if they think that they are a good, if not an outstanding, performer. So I think that that again has had some impact on what people now expect at senior level.

HR manager

This comment about relative reward, reflecting back to the symbolic value of the PRP, was echoed again in comments on fairness:

Q: If I can turn it around, forgive the impertinence, do you work harder because you get more money?

A: No. I don't. But it comes back to a very different element, which is the value you consider yourself to be worth for a job well performed.

CEO

One final aspect of the fairness discussion was fairness to shareholders - not paying large amounts to executives when shareholders had suffered a loss in the year. This was commented upon by participants discussing alignment of executives and shareholders (for example, through long-term schemes or share ownership). It was also mentioned in the context of PRP:

Because generally I think people do feel that they should not be paying the highest level of salaries or total income without there being some re- lationship to delivery to shareholders. I think those are the key reasons. It's not about motivation. Yes, there will be the weasel words in their proposals to shareholders, but it is not about motivation. The people that they are directing these plans at are self motivated; it's not going to come from the opportunities of big pay outs.

Consultant

From these various discussions of fairness, we can see a clear link into equity theory. Pay is considered fair by the executives if it relates their pay to that of their peers within the company and in other companies. Betterperforming directors (who perhaps have greater inputs) get paid more. It is the relativity that is important, rather than the absolute amount of pay. There is also a legitimacy theory explanation; being fair to the shareholders means that the sums involved can be justified.

\section{The need to provide alignment}

Again we refer back to the agency theory concept that directors and shareholders have fundamentally different objectives, and the remuneration contract needs to align directors' interests with those of the shareholders. The main way in which this is done is through the use of long-term incentives, rather than the annual bonuses discussed earlier, as it is longterm alignment which is required. Two issues arise. Firstly, any incentive has the potential to distort behaviour, and long-term incentives are needed to ensure that the short-term actions encouraged by the annual bonus scheme do not adversely impact upon longterm decision-making; a balance is needed. The second alignment issue is that it is often considered that if the directors own equity in the company their interests will be more aligned with the shareholders', and long-term incentives are one way to enhance directors' ownership. The issue of share ownership is outside the scope of this paper and is not pursued further.

A particular challenge relating to longer term performance-related pay is that conditions when the award period ends may have changed considerably from those which pertained when the performance measures and targets were set. External conditions - perhaps simplistically described as luck - could impact on performance positively or negatively, thus meaning that executives could claim unearned awards, or fail to achieve an award despite good performance. It is perhaps fair to state that none of the people interviewed appear to have taken issue with high awards being made for good luck, although several mentioned the negative impact of factors outside 
their control. This is in line with the findings of Garvey and Milbourn (2003), who suggested that companies are more concerned with the retention risk of losing executives who do not receive an award due to "bad luck" than they are with the risk of overpaying executives for good luck.

I think again the same is true of the long-term. The average employee can't affect the share price performance, whereas your top executive can. But the longer you go out, I think the less sharp an incentive it is. Particularly when it's share price, there are so many different factors that are going to influence what the share price does.

Consultant

All of the companies in the sample, and indeed the majority of large listed companies (New Bridge Street Consultants, 2002a) use performance-related long-term rewards as part of their directors' remuneration packages. However, despite the diversity of the industries in which they operate, it is almost universal that "long term" is defined as three years. This in part reflects the sentiments discussed above, that the performance targets are difficult to judge over longer periods.

... no plan is going to work if it goes beyond the time horizon of an executive participant population. And in my view it's very difficult to see that beyond three years.... I think you would also have to say that if we're talking about meaningful performance targets, and I don't believe that plans adopted for five or ten years should actually incorporate a defined performance measure along with targets...

Consultant

The problem with longer term targets being affected by luck can be explained in part using expectancy theory. This suggests that if the directors believe that achievement of the award is going to be affected by factors outside their control, it is less likely to motivate them. Hence plans are designed that give more control to the executives.

The other explanation for the ubiquity of the three-year performance period is an institutional theory one. A few interviewees explained that a statement from the $\mathrm{ABI}$ in the early eighties had used a period of three years as its example of a longer term scheme, and that this had been universally adopted. Furthermore, it was suggested that the three years had been chosen as an example because it fitted in with Inland Revenue rules for share options at that time, so there was little business logic behind it. Since then, as more companies have adopted three-year performance measurement terms, it has become accepted practice; this appears to be an illustration of mimetic isomorphism in practice. Furthermore, it might be seen as disadvantageous to a company to use a longer performance period, as companies are in competition to attract and retain good executives, and a longer period would be seen as a negative by the executives.

\section{Other reasons for using performance-related pay}

The reasons discussed above suggest that performance-related pay is used in order to encourage certain behaviour from the directors. This is a matter internal to the company with, as one committee chairman stated, remuneration being "the principal link between the individuals and the company". However, the results of the research indicated that external factors also came into play when companies were deciding whether to implement a performance-related reward scheme. The two main such reasons, which are interconnected, were market practices and the need for legitimacy.

Many of the interviewees mentioned that they had a performance-related pay scheme because it was market practice so to do. The explanations for this were two-fold. One, related to fairness, came back to the idea that the directors have to perceive pay structures as being fair between themselves and their peers in other companies, giving them the same earnings opportunities, and being a structure with which they were accustomed.

I think most of our senior executives would never have worked anywhere where a flat fee reward structure would be the norm for them. So it would be kind of out of left field really for them. I don't think any of the current top team would have worked anywhere where that was the reward regime.

HR director

A second matter raised in this area by many participants related to the perceived need to use PRP because that was "best practice" and good corporate governance.

I think because corporate governance says is that an element of salaries should relate to performance. I'm highly sceptical myself as to how much extra people really put in.

CEO

It's seen to be a good thing. That's the cynical answer.

Consultant

But you need a bonus structure, because everybody else has a bonus structure, and it's con- 
ventional wisdom that's the best way to pay people.

Because they're directed that way by corporate governance standards; because they think it's the right thing to do.

Consultant

... because a third of the total remuneration is "performance related". So you can write that down in the report and accounts, and when anybody questions you, you say "we're complying with best corporate governance of the moment, and we have a substantial part of pay which is variable and subject to performance, etc. etc.".

Consultant

Another respondent mentioned that performance-related pay was used because "the government likes it". Certainly, this is the case: both the DTI $(1999,2002)$ and the Combined Code (2003, principle B1) have emphasised the importance of a link between directors' pay and company performance. Thus the ubiquity of PRP can also be seen as an example of coercive isomorphism, with companies choosing to follow the Combined Code rather than explain their non-compliance.

One of the interviewees, a consultant, referred to another company he advised, which had been requested by the investing institutions to implement a long-term performance-related pay scheme. The sole reason given for this request was that the majority of other companies had such a scheme; there was no company-specific need for such an addition to the package. This again relates to the idea of using performance-related pay as a legitimising device, attracting stakeholder support by meeting with best practice.

\section{Problems with performance-related pay}

Before leaving this part of the discussion, it is worth noting that although the use of PRP is universal, many of the interviewees acknowledged its flaws.

I think, just by way of background, that is one of the fundamental problems in this area, the myth that it's easy to link pay to performance, when in fact it's so terribly difficult to do. You come up with so many unpredictable, volatile results that, particularly as measured over the long-term, it can become something of a lottery.

Consultant

The first thing to say is that performance-related pay is the Holy Grail of companies. I mean, if somebody had actually got there, really achieved it, then we'd all be following like mad - but nobody has.

HR director

The main issues underlying these comments include the difficulty in selecting appropriate performance measures and targets (that align with the company's objectives, are fair and do not overly distort behaviour); the ability (or not) of PRP to incentivise; and the influence of luck on the achievement or otherwise of results and payouts, particularly with equitybased schemes. The interviewees understood these problems, and tried to mitigate them where possible. Nevertheless, the arguments in favour of PRP (both HR and institutional/legitimacy) were such that they considered it to be necessary to implement these schemes.

\section{Discussion and conclusions}

UK listed companies use performance-related rewards for their executives, and the evidence is that the use of such awards is increasing. In this paper I have examined the reasons why this might be. By interviewing individuals involved with setting directors' remuneration, this research has opened up a new dimension in the debate. Against a theoretical background of agency theory, motivational theories and institutional and legitimacy theories, I have demonstrated how these tenets are perceived by the individuals directly involved, and shown that companies adopt performance-related pay despite a widespread belief that it does not necessarily motivate executives.

Three types of theory were introduced at the start of this paper as possible explanations for companies' use of PRP schemes: agency theory, motivation theories (expectancy, equity), and institutional and legitimacy theories.

Agency theory forms the basis for most of the academic literature on executive reward, and certain aspects of it were seen in the way in which directors' contracts are constructed to link pay to performance. Prendergast (1999) suggested that remuneration is structured to induce directors to work harder and to mitigate their natural risk-averseness: the research evidence suggests that this is not the case. Many of the interviewees did not believe that variable pay motivated executives to work harder, and risk-taking was rarely mentioned in their discussions. However, agency theory was relevant in relation to the multi-tasking issues, where performance measures and targets are designed to focus directors' efforts in the direction desired by the board. 


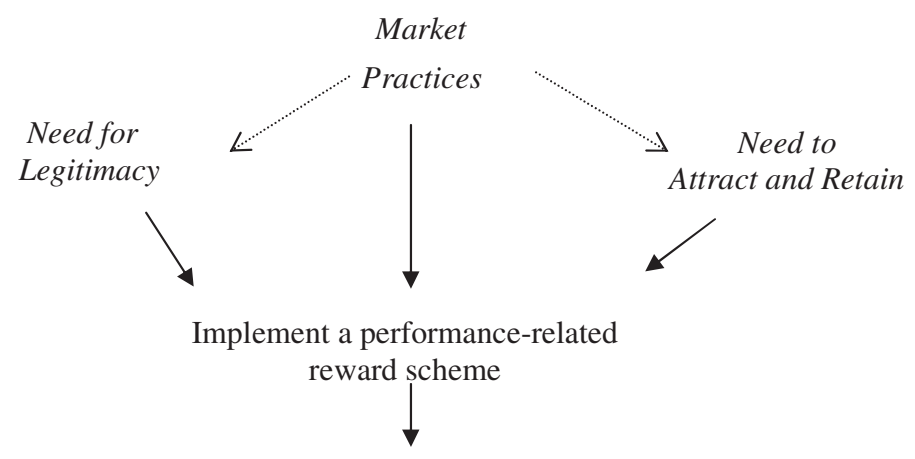

Set performance measures and targets and use it to communicate strategy This will affect

Directors' actions and behaviours

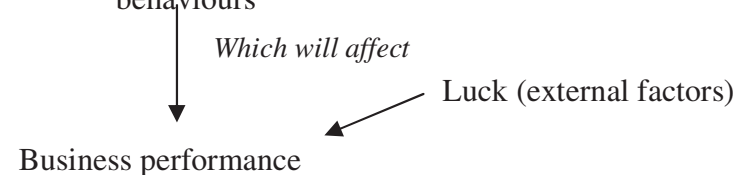

Business performance

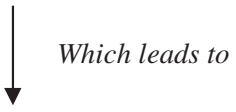

Performance-related award

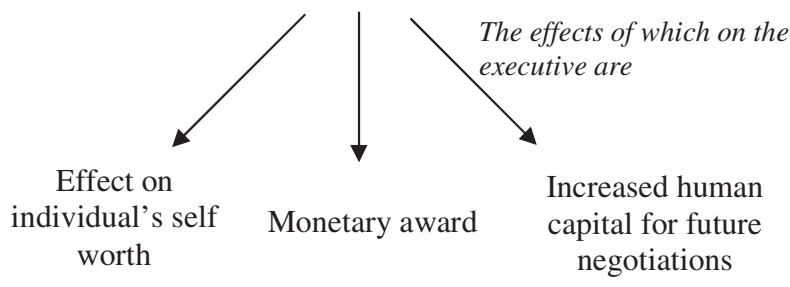

Figure 1: Why companies use performance-related pay

Of the motivational theories considered in this paper, there was little evidence of expectancy theory as a driver for using performance-related contracts, but considerable evidence for equity theory. This was shown in the need for contracts to be perceived as fair by executives, when comparing to their internal and external peers. It was evidenced in discussions that indicated that the relative level of pay was more important than the absolute level.

The final theoretical lens was that of institutional theory, and the related concept of legitimacy. There was strong evidence that both coercive and mimetic isomorphism act to ensure that companies use PRP. Furthermore, the interviewees were concerned to ensure that their companies' practices were seen as legitimate in the eyes of their stakeholders, particularly the institutional shareholders.

The themes that have emerged from the interviews reported in this paper are set out in
Figure 1, which illustrates that there are three main reasons why companies implement performance-related pay schemes. The first is current market practice, which in turn influences the other two: the companies' need for legitimacy, and their need to attract and retain good executives. By following market practice in structuring their executive packages, the companies are not standing out from the crowd, and are likely to draw support from relevant constituencies, in particular the institutional shareholders (although customers and employees were perceived as important stakeholders too). ${ }^{3}$ Furthermore, in structuring packages in the same manner as others, companies are remaining competitive in the marketplace for executives, whilst not losing this legitimacy by being perceived to offer an excess of riches.

The schemes are used to set performance measures and targets that will communicate 
the company's strategy, and which are intended to influence directors' actions and behaviours towards implementing that strategy. This is intended to affect business performance (despite interviewees' comments that pay does not motivate). However, even the most sophisticated pay scheme and the most accomplished directors may not produce the expected or desired performance - there is also the influence of external factors, "luck", which may enhance or detract from the business results. Ultimately, if the required performance is achieved, the success will be rewarded.

The reward itself has three outcomes. Most obviously, it provides a monetary award (cash or equity) for the director. Secondly, achieving the reward increases his self esteem, providing an ego boost as he compares himself with his peers. The final outcome of achieving the reward is that it improves the executive's track record, increasing his human capital for future pay negotiations.

Whilst this small sample of companies and interviewees is not generalisable, it has informed theory in the areas discussed, demonstrating how agency theory, motivational theories and institutional theory and legitimacy have a place to play in explaining what is happening. Each of these theories on its own is an incomplete explanation of why companies use performance-related remuneration, but together they explain behaviour more fully.

Further research is needed to determine how the various factors identified in this study influence companies in different circumstances. Also, given the UK background of this research, it would be useful to investigate how the work translates in to other countries, many of which use the same type of governance codes. Given that there is an increasing requirement internationally for companies to use performance-related pay to reward their executives, an appreciation of how it understood by those charged with setting remuneration policies can inform practice as well as theory.

\section{Acknowledgements}

The financial support of the P D Leake Trust (a charity associated with the ICAEW) is gratefully acknowledged. The Centre for Business Performance manages all grant applications.

\section{Notes}

1. The register was used to create a list of companies from the FTSE 350 that appeared to comply with best practice in corporate governance. The original research design was to select companies in the utilities and finance sectors, although this was later broadened to include other sectors.

2. Board and director appraisal is now a requirement of the Combined Code (2003, para A.6).

3. On occasion, institutional shareholders become dissatisfied with current market practice, and force changes. This is an example of coercive isomorphism. It can be seen in recent months in the change to payoffs to exiting directors, and to the decline in use of performance re-testing for longterm schemes. See, for example, Financial Times (2004).

\section{References}

Adams, J. S. (1963) Towards an Understanding of Inequity, Journal of Abnormal and Social Psychology, 67, 422-436.

Ambrose, M. L. and Kulik, C. T. (1999) Old Friends, New Faces: Motivation Research in the 1990s, Journal of Management, 25, 231-292.

Association of British Insurers (2002) Guidelines for Share Incentive Schemes, February. London: Association of British Insurers.

Bender, R. (2003) How Executive Directors' Remuneration is Determined in Two FTSE 350 Utilities, Corporate Governance: An International Review, 11, 206-217.

Bonner, S. E. and Sprinkle, G. B. (2002) The Effects of Monetary Incentives on Effort and Task Performance: Theories, Evidence, and a Framework for Research, Accounting, Organizations and Society, 27, 303-345.

Combined Code on Corporate Governance (2003) London: Financial Reporting Council.

Conyon, M. J., Peck, S. I., Read, L. E. and Sadler, G. V. (2000) The Structure of Executive Compensation Contracts: UK Evidence, Long Range Planning, 33, 478-503.

Cornell Law School, Legal Information Institute (undated) US Code Collection, section 162(m), accessed from http://www4.law.cornell.edu/ uscode/26/162.html on 23 March 2004.

Davis, J. H., Schoorman, F. D. and Donaldson, L. (1997) Towards a Stewardship Theory of Management, Academy of Management Review, 22, 20-47.

Deci, E. (1972) The Effects of Contingent and Noncontingent Rewards and Controls on Intrinsic Motivation, Organizational Behavior and Human Performance, 8(2), 217-229.

Department of Trade and Industry (1999) Directors' Remuneration: a Consultative Document. London: Department of Trade and Industry.

Department of Trade and Industry (2002) The Directors' Remuneration Report Regulations 2002. Statutory Instrument 2002 No. 1986. London: Department of Trade and Industry.

DiMaggio, P. J. and Powell, W. W. (1983) The Iron Cage Revisited: Institutional Isomorphism and Collective Rationality in Organizational Fields, American Sociological Review, 48, 147-160. 
Eisenhardt, K. M. (1989) Agency Theory: An Assessment and Review, Academy of Management Review, $14,57-74$.

Financial Times (2003) Skandia UK Boss Defends Bonus, Financial Times, 8 December.

Financial Times (2004) First Choice Plans Changes to Options, Financial Times, 16 February.

Garvey, G. T. and Milbourn, T. T. (2003) Asymmetric Benchmarking in Compensation: Executives are Paid for (Good) Luck But Not Punished for Bad, AFA 2004 San Diego Meetings, http:/ /ssrn. com/abstract $=392701$

Harrison, J. R. (1987) The Strategic Use of Corporate Board Committees, California Management Review, Fall, 109-125.

Hart, O. (1995) Corporate Governance: Some Theory and Implications, The Economic Journal, 105, 678-689.

Holstrom, B. and Milgrom, P. (1991) Multitask Principal-Agent Analyses: Incentive Contracts, Asset Ownership, and Job Design, The Journal of Law, Economics and Organization, 7, 24-52.

Indjejikian, R. (1999) Performance Evaluation and Compensation Research: An Agency Perspective, Accounting Horizons, 13, 147-157.

Jensen, M. C. and Meckling, W. H. (1976) Theory of the Firm: Managerial Behaviour, Agency Costs and Ownership Structure, Journal of Financial Economics, 3, 305-360.

Maslow, A. H. (1970) A Theory of Human Motivation. In V. H. Vroom and E. L. Deci (eds) Management and Motivation. Harmondsworth: Penguin Education, pp. 27-41.

Merchant, K. A., Van der Stede, W. A. and Zheng, L. (2003) Disciplinary Constraints on the Advancement of Knowledge: The Case of Organizational Incentive Systems, Accounting, Organizations and Society, 28, 251-286.

Miles, M. B. and Huberman, A. M. (1994) Qualitative Data Analysis. London: Sage.
Milkovich, G. T. and Newman, J. M. (2002) Compensation. New York: McGraw-Hill.

New Bridge Street Consultants (2002a) Paying for Performance: Executive Long-Term Incentives in FTSE 350 Companies, March. New Bridge Street Consultants.

New Bridge Street Consultants (2002b) Survey of Annual Bonus Schemes in FTSE 350 Companies, August. London: New Bridge Street Consultants.

OECD (2004) OECD Principles of Corporate Governance: Draft Revised Text, January 2004, accessed from http://www.ecgi.org/codes/country documents/oecd/draft_revised_text_en.pdf on 16 February 2004.

Osterloh, M. and Frey, B. S. (2002) Does Pay for Performance Really Motivate Employees?, In A. Neely (ed.) Business Performance Measurement: Theory and Practice. Cambridge: Cambridge University Press, pp. 107-122.

Prendergast (1999) The Provision of Incentives in Firms, Journal of Economic Literature, 37, 7-63.

Scott, W. R. (1995) Institutions and Organizations. London: Sage.

Suchman, M. C. (1995) Managing Legitimacy: Strategic and Institutional Approaches, Academy of Management Review, 20, 571-610.

The Economist (2003) Fat Cats Feeding, The Economist, 9 October.

Vroom, V. H. (1964) Work and Motivation. New York: Wiley.

Yin, R. K. (1993) Applications of Case Study Research. London: Sage.

Ruth Bender is a lecturer in finance at Cranfield School of Management. Prior to becoming an academic, she was a corporate finance partner with Grant Thornton. She is currently completing a PhD at Warwick Business School, researching how large UK companies determine the pay of their executive directors. 